\title{
PENGALAMAN PERAWAT MELAKUKAN LATIHAN AKTIFITAS FISIK PADA PASIEN CONGESTIVE HEART FAILURE
}

\author{
Nursing Experiences Exercise Physical Activity in Patient Congestive Heart Failure
}

\author{
Deni Susyanti ${ }^{1}$, Mompang Tua Parlagutan ${ }^{2}$, Muchti Yuda Pratama ${ }^{3}$ \\ ${ }^{1,2,3}$ Dosen Tetap Akper Kesdam I/Bukit Barisan Medan \\ Email : deni_susyanti@yahoo.co.id, yudamuchti@yahoo.co.id
}

\begin{abstract}
Abstrak
Penderita congestive heart failure (CHF) sangat memerlukan program rehabilitatif yang komprehensif untuk mengembalikan kemampuan fisik paska serangan serta mencegah terjadinya serangan ulang. Latihan fisik pada penderita congestive heart failure (CHF) bertujuan untuk mengoptimalkan kapasitas fisik tubuh, memberi penyuluhan pada pasien dan keluarga dalam mencegah perburukan dan membantu pasien untuk kembali dapat beraktifitas fisik seperti sebelum mengalami congestive heart failure (CHF). Penelitian ini bertujuan untuk mengeksplorasi secara mendalam pengalaman perawat melakukan latihan aktifitas fisik pada pasien congetive heart failure. Desain penelitian yang digunakan adalah fenomenologi deskriptif. Partisipan dalam penelitian ini berjumlah 6 partisipan yang dipilih dengan teknik purposive sampling. Data yang dikumpulkan berupa rekaman hasil wawancara mendalam (in-depth interview) dilengkapi dengan catatan lapangan (field note) kemudian dibuat dalam bentuk kata demi kata dan dianalisis dengan menggunakan pendekatan Colaizzi's. Hasil penelitian ditemukan empat tema, yaitu: pelaksanaan latihan aktifitas fisik pasien congestive heart failure belum optimal; peningkatan pengetahuan perawat dan pasien; perlunya dukungan dari pihak rumah sakit; dan harapan terhadap pelaksanaan latihan aktifitas fisik. Hasil penelitian menunjukkan bahwa hal- hal yang dapat mempengaruhi latihan aktifitas fisik pada pasien congestive heart failure adalah adanya standar operasional prosedur, pengetahuan perawat, adanya dukungan dari pihak rumah sakit; dan harapan terhadap pelaksanaan latihan aktifitas fisik. Penelitian ini memberikan gambaran pemahaman perawat tentang latihan aktifitas fisik sehingga perawat mampu memberikan asuhan keperawatan yang tepat.
\end{abstract}

Kata kunci: pengalaman, latihan aktifitas fisik, congetive heart failure

\begin{abstract}
People with congestive heart failure (CHF) need a comprehensive rehabilitative program to restore physical abilities post-attacks and prevent re-attacks. Physical exercise in congestive heart failure (CHF) patients is aimed at optimizing the physical capacity of the body, providing counseling to patients and families in preventing worsening and helping patients to return to physical activity as before congestive heart failure (CHF). This study aims to explore in depth the experience of nurses doing physical exercise exercises in congetive heart failure patients. The research design used is descriptive phenomenology. Participants in this study amounted to 6 participants selected by purposive sampling technique. The data collected were in-depth interviews completed with field notes and then made in verbatim and analyzed using Colaizzi's approach. The research results found four themes, namely: the implementation of physical exercise exercise congestive heart failure patient is not optimal; increased knowledge of nurses and patients; the need for support from the hospital; and expectations for the exercise of physical activity. The results showed that things that could affect physical exercise activity in congestive heart failure patients were standard operating procedures, nurse knowledge, hospital support; and expectations for the exercise of physical activity. This study provides an understanding of the nurse's understanding of physical activity exercises so that nurses are able to provide appropriate nursing care.
\end{abstract}

Keywords: experience, physical activity exercise, congetive heart failure

\section{PENDAHULUAN}

Gagal jantung adalah ketidak-mampuan jantung untuk memompa darah yang adekuat untuk memenuhi kebutuhan jaringan akan oksigen dan nutrisi. Penyebabnya ini adalah kelainan otot jantung dan penyakit jantung 
lain yang mengakibatkan curah jantung lebih rendah dari curah jantung normal (Downing $\&$ Balady, 2011).

Insiden gagal jantung mengalami peningkatan secara konsisten, walaupun terjadi kemajuan teknologi dalam diagnostik dan penatalaksanaan gagal jantung. Di Amerika Serikat 5,7 juta orang menderita gagal jantung, 670.000 kasus baru diagnosa setiap tahun. American Heart Association memperkirakan biaya yang dibutuhkan untuk pasien jantung \$33 juta setiap tahun (American Heart Association, 2013). Meskipun akhir- akhir ini banyak kemajuan dalam hal evaluasi dan penanganan gagal jantung, terjadinya gagal jantung simtomatis masih membawa prognosis yang buruk (Loscalzo, 2014). Penyakit jantung saat ini menduduki urutan pertama penyebab kematian di Indonesia, sekitar $25 \%$ dari seluruh kematian hampir disebabkan oleh gangguan kelainan jantung (Kementerian Kesehatan RI, 2013). Berdasarkan data Rekam Medis prevalensi pasien rawat inap di Rumkit Tk II Putri Hijau Tahun 2016 jumlah pasien gagal jantung adalah Triwulan III sebanyak 61 orang dan Triwulan IV sebanyak 31 orang.

Melihat prevalensi penyakit jantung diatas diketahui bahwa jumlah penyakit jantung semakin hari semakin bertambah begitu juga dengan kejadian dengan kejadian rawat inap ulang. Salah satu upaya yang diperlukan untuk menurunkan prevalensi dan menekan lajunya rehospitalisasi pada pasien congestive heart failure (CHF) tersebut adalah dengan cara mengoptimalkan status kesehatan, dengan merubah gaya hidup dan melakukan rehabilitasi jantung yakni mobilisasi (Arofah, 2010).

Ketidakpatuhan responen dalam terapi gagal jantung merupakan hal yang sering terjadi, diperkirakan 40-60\% tidak patuh terhadap pengobatan dan 43-93 \% tidak patuh terhadap perubahan gaya hidup (Schub \& Cabrera, 2010). Rendahnya kepatuhan ini mengakibatkan tingginya angka dirawat ulang pada pasien gagal jantung.

Penderita congestive heart failure (CHF) sangat memerlukan program rehabilitatif yang komprehensif untuk mengembalikan kemampuan fisik paska serangan serta mencegah terjadinya serangan ulang. Latihan fisik pada penderita congestive heart failure (CHF) bertujuan untuk mengoptimalkan kapasitas fisik tubuh, memberi penyuluhan pada pasien dan keluarga dalam mencegah perburukan dan membantu pasien untuk kembali dapat beraktifitas fisik seperti sebelum mengalami congestive heart failure (CHF) (Arofah, 2010).

Latihan aktivitas yang disesuaikan dengan toleransi pasien gagal jantung menjadi salah satu intervensi yang dapat dilakukan. Latihan aktivitas yang disesuaikan dengan toleransi bertujuan untuk meminimalkan kebutuhan (demand) oksigen tubuh sehingga metabolisme anaerob dapat dikurangi. Selain itu,latihan aktivitas bermanfaat untuk melatih jantung beradaptasi dengan kapasitasmaksimal dalam menjalankan fungsinya.

Hasil review sistematis yang dilakukan oleh Pollentier, Irons, Marie, Diane, dan Newton (2010) tentang examination of the $6 M W T$ to determine fungtional capacity in people with chronic heart failure menyatakan bahwa korelasi antara Six minute walk test (6MWT) dengan konsumsi oksigen maksimal (VO2 max) adalah sedang-kuat. Terdapat korelasi yang kuat jika pasien mempunyai hasil Six minute walk test $(6 \mathrm{MWT})<300$ meter atau konsumsi oksigen maksimal rendah $(<10 \mathrm{~mL} / \mathrm{kg} / \mathrm{min})$. Six minute walk test mempunyai nilai prediksi yang rendah terhadap $\mathrm{VO} 2$ max jika pasien mempunyai konsumsi oksigen maksimal tinggi. Six minute walk test sangat sesuai untuk alat ukur dalam pemantauan serial atau respon terhadap suatu intervensi (Pollentier, Irons, Enedetto, Dibenedetto, Loton, \& Seyler, 2010).

Kapasitas fungsional dapat ditingkatkan, salah satunya dengan melakukan latihan fisik. Latihan aktivitas fisik yang benar, teratur dan terukur untuk mencapai kebugaran yang optimal (Muizzah, 2013). Latihan fisik yang berupa mobilisasi ringan sudah dapat dilakukan sejak 48 jam setelah gangguan jantung sepanjang tidak terdapat ada kontraindikasi. Latihan fisik yang dilakukan terbatas pada aktivitas sehari- hari misalnya gerakan tangan dan kaki dan 
pengubahan postur. Program latihan biasanya berupa terapi fisik ambulatory yang diawasi.

Berdasarkan penelitian yang dilakukan oleh Downing dan Balady (2011); Chung dan Schulze (2011) menyatakan bahwa latihan olahraga terbukti memperbaiki beberapa hal seperti adanya perubahan perbaikan terhadap pada otot rangka, pembuluh darah dan sistem ventilasi pasien CHF.

Dari studi pendahuluan yang dilakukan oleh Badriyah (2013), Yenni, Nurchayati, dan Sabrian (2014) menyatakan bahwa belum dilaksanakannya rehabilitasi jantung secara benar dan kontinu, ketidakpatuhan pasien gagal jantung untuk melakukan latihan rehabilitasi masih tinggi dimana 4 dai 5 pasien gagal jantung yang di survey mengatakan tidak mengetahui tentang latihan rehabilitasi jantung, pasien tersebut mengakui tidak pernah melakukan latihan rehabilitasi jantung selama di rumah karena tidak ada teman untuk melakukan kegiatan tersebut.

Berdasarkan hasil penelitian di atas menunjukkan bahwa pengalaman perawat melakukan latihan aktifitas fisik pada pasien congestive heart failure sangat penting untuk digali sehingga dapat menentukan program latihan aktifitas fisik pada pasien congestive heart failure dan meningkatkan hasil rehabilitasi pasien congestive heart failure. Untuk itu penelitian ini akan mempelajari secara mendalam tentang berbagai persepsi atau pengalaman perawat melakukan latihan aktifitas fisik pada pasien congestive heart failure.

\section{METODE PENELITIAN}

1.1. Lokasi Penelitian

Penelitian dilakukan di Rumkit Tk II Putri Hijau dengan mengambil data dari Perawat Rumkit Tk II Puri Hijau. Pengambilan data tentang informasi pertisipan dilakukan di rumah sakit tersebut karena merupakan rumah sakit rujukan untuk kawasan daerah Barat.

\subsection{Metode}

Penelitian dilakukan pada Mei-Juli. Penelitian menggunakan studi kualitatif dengan desain fenomenologi deskriptif.
Desain ini dipilih agar pengalaman partisipan dapat dieksplorasi menjadi lebih terungkap sehingga gambaran pengalaman perawat melakukan latihan aktifitas fisik dapat tergambar secara nyata. Selain itu, penelitian ini melakukan eksplorasi, analisis dan deskripsi secara langsung fenomena pengalaman perawat dalam melakukan latihan aktifitas fisik.

Partisipan dalam penelitian ini 6 orang perawat ruang rawat inap dengan menggunakan teknik purposive sampling. Pengumpulan data dilakukan wawancara mendalam (in-depth interview), dan catatan lapangan (field note) ) kemudian dibuat dalam bentuk kata demi kata dan dianalisis dengan menggunakan pendekatan Colaizzi's. Pada penelitian ini juga memperhatikan keandalan data dan prinsip etika penelitian.

\section{HASIL}

Peneliti mengumpulkan data dengan metode in-depth interview dan field note. Hasil wawancara berupa transkrip tertulis dilakukan content analysis. Berdasarkan hasil analisis ditemukan 4 tema yaitu:

1) pelaksanaan latihan aktifitas fisik pasien congestive heart failure belum optimal.

Perawat ruang rawat inap rumkit Tk II Putri Hijau sering mengalami keterbatasan dalam melakukan latihan aktifitas fisik pada pasien congestive heart failure. Partisipan menyatakan meskipun SPO sudah ada tapi perlu dilakukannya revisi, dan masih adanya anggapan bahwa aktifitas fisik pada pasien congestive heart failure sebaiknya dibatasi serta dengan adanya SPO akan dijadikan dasar dalam melakukan latihan aktifitas fisik pada pasien congestive heart faiure. Hal ini sesuai dengan pernyataan partisipan:

"...yah pada dasarnya itu memang harus dilaksanakan karena selama ini kita berpedoman kepada standart asuhan keperawatan, jadi khusus pada pasien CHF adalah kasus dari penyakit jantung, kemudian SPO yang adapun...eee....dengan berkembangnya ilmu pengetahuan dia perlu di revisi karena dengan adanya SPO yang telah kita buat berapa ribu SPO sebagai asuhan perawatannya, kemudian seingat saya ....ee... [Patisipan 1]. 
“......kemudian perumusan dari pada SPO pun untuk latihan aktifitas fisik pada pasien CHF ini sudah sebelumnya kita berikan kepada pasien hanya saja kita tinggal memilah milah kasusnya yang bagaimana seperti yang kita ketahui CHF kan ada grad-grad nya, pada pasien CHF yang akut dengan $\mathrm{CHF}$ itu kita harus melihat dulu keadaan umumnya memperhatikan TTVnya, seperti tekanan darah, RR, Pols, Temp, $H R$, kalaulah pasien itu dikategorikan yang akut atau mungkin ada nyeri dada yang hebat biasanya sih kita belum memulai dari pada aktifitas itu karena kita harus mempertimbangkan dari pada kondisinya pasien, untuk selama ini bagi pasien pasien yang dikategorikan tidak akut kita sudah melaksanakan itu latihan fisik kita sudah laksanakan seperti mobilisasi-mobilisasi ataupun latihanlatihan fisik di hari pertama, cuma kita tetap berkolaborasi dengan dokter spesialis jantung, ......." [Patisipan 2].

“....., itu perlu sekali buk, biar bisa di terapkannya di sini, di karena kan dengan adanya SPO kita tidak akan melakukan hal-hal yang diluar dari penyakit tersebut" [Patisipan 3].

Partisipan menyatakan bahwa aktifitas fisik pasien congestive heart failure harus dibatasi. Pernyataan ini sesuai dengan ungkapan partisipan:

...."yang selama ini dilaksanakan adalah pasien-pasien CHF untuk aktifitas sehariharinya dibatasi, karena takut terjadi misalnya takut serangan kembali, yah tapi SPO yang kita anut ini layak lah tapi belum sempurna cuman kita yang melaksanakan itu seтиa ada aturan termasuk dari dokter yang merawat." [Patisipan 2].

2) Peningkatan pengetahuan perawat dan pasien.

Kurangnya pengetahuan perawat tentang latihan aktifitas fisik pada pasien congestive heart failure serta kurangnya sumber daya manusia yang terlatih. Penyataan sesuai dengan ungkapan: “......kendala yang paling utama yaitu masih adanya faham yang lama kalau penyakit jantung ini tidak perlu atau tidak dimobilisasi berlebihan, takut itu tadi serangan susulan atau komplikasi lain, ya..." [Patisipan 1].

"......pertama itu memang kita kendalanya itu ada di SDM kita lihat dari SDM itu kita perlu sosialisasi lagi kembali tentang latihan fisik yang bagaimana yang diberikan kepada pasien pasien yang CHF......" [Patisipan 2].

“...tapi kalau untuk pasien pasien $\mathrm{CHF}$ belum pernah mendapat suatu materi materi untuk latihan fisik ini yang sangat baik..." [Patisipan 2].

3) Perlunya dukungan dari pihak rumah sakit

Partisipan mengatakan bahwa dalam melakukan latihan aktifitas fisik pada pasien congestive heart failure sebaiknya ada keterlibatan dengan tim medis lainnya. Penyataan sesuai dengan ungkapan:

"... perlu keterlibatan dari bagian pisiotheraphy mungkin nanti kita bisa juga mengikut sertakan fisioteraphy latihan latihan fisik ini kepada pasien pasien CHF..." [Patisipan 4].

Partisipan mengatakan perlu adanya sarana dan prasaran untuk mendukung latihan aktifitas fisik pasien congestive heart failure. Penyataan sesuai dengan ungkapan:

".......menyediakan alat-alat treatmeal biasanya itukan ada alat khusus diruangan poli jantung tidak ada diruangan kita atau misalnya dia latihan turun naik tangga kan...." [Patisipan 5].

4) harapan terhadap pelaksanaan latihan aktifitas fisik

Perawat ruang rawat inap dalam melakukan latihan aktifitas fisik pada pasien congestive heart failure mengharapkan akan melakukan asuhan keperawatan dengan tepat. Pernyataan ini sesuai dengan ungkapan:

“....... ya untuk kesembuhan yang jelas ya, walaupun tidak sembuh secara sempurna 
karena saat ini yang terjadi sedikitsedikit pasien kalau sudah nyeri, harus di ultimatum harus pasang ring harus pasang cincin dengan biaya yang sangat mahal, sebenarnya dasar daripada penyembuhan itu adalah perawatan dalam bentuk asuhan perawatan..."[Partisipan 1]

“...kita bisa menganalisa secara cepat dan memutuskan asuhan keperwatan mana yang lebih bagus sehingga kita tidak menunggu therapy dari dokter......'[Partisipan 6]

Partisipan menyatakan dapat menekan cost rumah sakit. Pernyataan tersebuat sesuai yag diungkapkan oleh partisipan:

"...manfaat nya pasiennya bisa cepat pulih kembali, kemudian bisa menekan eee....cost, mungkin bisa melatih keterampilan perawat agar lebih optimal yang selama ini belum optimal membiasakan terbentuk nya komunikasi yang baik antara perawat dengan pasien..." [Partisipan 2]

\section{PEMBAHASAN}

Downing dan Balady (2011); Chung dan Sculze (2011) menyatakan bahwa latihan olahraga terbukti memperbaiki beberapa hal seperti adanya perubahan perbaikan terhadap pada otot rangka, pembuluh darah dan sistem ventilasi pasien CHF [4][5]. Dari studi pendahuluan yang dilakukan oleh Badriyah (2013), Yenni, Nurchayati, dan Sabrian (2014) menyatakan bahwa belum dilaksanakannya rehabilitasi jantung secara benar dan kontinu, ketidakpatuhan pasien gagal jantung untuk melakukan latihan rehabilitasi masih tinggi dimana 4 dari 5 pasien gagal jantung yang di survey mengatakan tidak mengetahui tentang latihan rehabilitasi jantung, pasien tersebut mengakui tidak pernah melakukan latihan rehabilitasi jantung selama di rumah karena tidak ada teman untuk melakukan kegiatan tersebut [3][12].

Temuan penting dalam penelitian ini berkaitan dengan masalah pelaksanaan latihan aktiftas fisik pada pasien congestive heart failure. Partisipan menyatakan bahwa perlu adanya SPO tentang latihan aktiftas fisik pada pasien congestive heart failure karena masih ada anggapan bahwa pasien dengan congestive heart failure sebaiknya harus istirahat, sedangkan sesuai dengan penelitian Arovah (2010) Penderita congestive heart failure (CHF) sangat memerlukan program rehabilitatif yang komprehensif untuk mengembalikan kemampuan fisik paska serangan serta mencegah terjadinya serangan ulang [2]. Latihan fisik pada penderita congestive heart failure (CHF) bertujuan untuk mengoptimalkan kapasitas fisik tubuh, memberi penyuluhan pada pasien dan keluarga dalam mencegah perburukan dan membantu pasien untuk kembali dapat beraktifitas fisik seperti sebelum mengalami congestive heart failure (CHF).

Kurangnya pengetahuan perawat tentang latihan aktifitas fisik pada pasien congestive heart failure serta kurangnya sumber daya manusia yang terlatih sehingga perlu adanya peningkatan pengetahuan perawat dengan cara pelatihan, seminar dan workshop tentang latihan aktifitas fisik yang harus diberikan kepada pasien congestive heart failure (CHF).

Perlu adanya dukungan dari pihak Rumah Sakit dengan adanya sarana dan prasaran guna mendukung penerapan latihan aktifitas fisik pada pasien congestive heart failure.

Harapan terhadap pelaksanaan latihan aktifitas fisik pada pasien congestive heart failure dengan adanya SPO yang sudah di revisi, dapat mendukung terhadap pemberian asuhan keperawatan khususnya pada pasien congestive heart failure sehingga setiap perawat di ruang rawat inap mempunyai dasar dalam melakukan latihan aktifitas fisik serta bagi rumah sakit dapat menekan cost rumah sakit.

\section{KESIMPULAN DAN SARAN}

Berdasarkan hasil penelitian ini dapat disimpulkan bahwa pengalaman perawat ruang rawat inap rumkit Tk II Putri Hijau mendapatkan tema yaitu: pelaksanaan latihan aktifitas fisik pasien congestive heart failure belum optimal; peningkatan pengetahuan perawat dan pasien; perlunya dukungan dari pihak rumah sakit; dan harapan terhadap pelaksanaan latihan aktivitas fisik. 
Tema yang muncul dalam penelitian ini dapat digunakan sebagai acuan bagi perawat ruang rawat inap dalam melakukan latihan aktifitas fisik pada pasien congestive heart failure. Perawat dalam memberikan asuhan keperawatan juga perlu memperhatikan kondisi dari pada pasien congestive heart failure sebelum melakukan latihan aktifitas fisik tersebut. Perawat di ruangan hendaknya memperhatikan dan melaksanakan program rehabilitasi jantung terutama latihan aktifitas secara bertahap.

\section{DAFTAR PUSTAKA}

American Heart Association. Coronary Artery Disease: Coronary Heart Disease. 2013. Available from: http://www.heart.org/HEARTORG/Con ditions/More/MyHeartand

StrokeNews/Coronary-Artery-Disease--The-ABCs-of-

AD_UCM_436416_Article.jspDownin $\mathrm{g}$ dan Balady (2011) The role of exercise training in heart failure. Journal of the American College o Cardiology. Published by Elsevier Inc. Vol. 58, No. 6.

Arofah, N.I. 2010. Program latihan fisik rehabilitatif pada penderita penyakit jantung.http://staff.uny.ac.id/sites/defau lt/files/132300162/3.\%20Progra\%20Lat ihan\%20Fisik\%20Rehabilitatif\%20Pad a\%20Penderita\%20Penyakit\%20\%20Ja ntung.pdf.

Badriyah, F.L. 2013. Latihan fisik terarah penderita post sindrom koroner akut dalam memperbaiki otot jantung. Tesis 2013. .

Chung, C.J., \& Schulze, P.C. 2011. Exercise as a nonpharmacologic intervention in patients with heart failure. The physician and sportmedicine, 39:4, 3743.

Loscalzo, J. 2014. Kardiologi dan pemuluh darah. Edisi 2. EGC

Kementerian Kesehatan RI. Badan Litbangkes Kementerian Kesehatan RI dan Data Penduduk Sasaran. Data Riset Kesehatan Dasar;2013:2-4

Muizzah, L. 2013. Hubungan Antara Kebugaran Dengan Status Gizi Dan
Aktivitas Fisik Pada Mahasiswi Program Studi Kesehatan Masyarakat Uin Syarif Hidayatullah Jakarta Tahun 2013.

Pollentier, Irons, S.L, enedetto, C.M, Dibenedetto, A.M., Loton, D., \& Seyler, R.D, 2010. Examination of the six minute walk test to determine functional capaciti in people with chronic heart failure: A systematic revie. Cardiopulmonary physical therapy journal.21:1.

Schub T \& Cabrera G. 2010, Hearth failure: Enhancing self management. Cinahl Information System.

Smeltzer, S.C., Bare, B.G., Hinkle, J.L., \& Cheever, K.H. 2010. Textook of medical surgical nursing. Brunner \& Suddarth's. Volume 1, Twelfth edition. Lippincoltt Williams \& Wilkins.

Yenni, E., Nurchayati, S., Sabrian, F., Perawat, M., Arifin, R., Pekanbaru, A., ... Universitas, K. 2013. Terhadap pengetahuan dan kemampuan mobilisasi dini pada pasien congestive heart failure (CHF). The purpose of this research was to identify the effect of health education of cardiac rehabilitation exercise to knowledge and ability of early mobilization. 